\title{
A spatial and temporal analysis of Sand Forest tree assemblages in Maputaland, South Africa
}

\author{
Jerome Y. Gaugris $^{1^{*}}$ \& Margaretha W. van Rooyen ${ }^{2}$ \\ Centre for Wildlife Management, University of Pretoria, Pretoria, 0002 South Africa \\ ${ }^{2}$ Department of Botany, University of Pretoria, Pretoria, 0002 South Africa \\ Received 15 February 2008. Accepted 3 September 2008
}

\begin{abstract}
Maputaland is a centre of plant endemism, within the Maputaland-Pondoland-Albany hotspot of biodiversity shared by Mozambique and South Africa. The Sand Forest vegetation is the most valuable vegetation type in this region due to the endemics it harbours, but it is currently under threat from growing animal population densities within conserved areas and from a growing human population outside. To improve our understanding of Sand Forest dynamics the present study investigated the woody plant assemblages in Tembe Elephant Park. A total of 59 plots were sampled and analysed using classification and ordination methods. The results indicate that Sand Forest in Tembe is a complex assemblage of at least three floristically and structurally distinct woody communities. An ordination of the combined results from the present study together with two other studies could link the floristics and structure of the Sand Forest to the level of disturbance by herbivores and humans. Large herbivores induce both structural and floristic changes in the Sand Forest of Tembe Elephant Park and a lack of disturbance in the nearby Tshanini Community Conservation Area leads to a state of equilibrium. The results therefore suggest that Sand Forest dynamics and complexity may be strongly linked to small- to medium-scale animal disturbance.
\end{abstract}

Key words: disturbance, forest structure, Maputaland, Sand Forest, succession, woody plant assemblages.

\section{INTRODUCTION}

The Forest Biome is the smallest biome in South Africa (Low \& Rebelo 1998). Eight zonal forest groups are distinguished in addition to one azonal forest group. Sand Forest is part of the Tropical Dry Forest group, which is found in Maputaland (Licuati Sand Forest) and in some parts of the Kruger National Park in South Africa (Nwambyia Sand Forest) (Mucina \& Rutherford 2006). The conservation of forests in South Africa is difficult because their distribution is patchy, and therefore large networks of interconnected patches are needed to conserve their species diversity and dynamics (Midgley et al. 1990; Everard et al. 1994; Everard et al. 1995; Low \& Rebelo 1998; Van Rensburg et al. 2000b; Lawes et al. 2004).

Licuati Sand Forest (hereafter referred to as Sand Forest) is confined to the Maputaland region of South Africa, which is part of the MaputalandPondoland-Albany hotspot of biodiversity (Mucina \& Rutherford 2006; Smith et al. 2006) and is also recognized as the Maputaland Centre of Plant Endemism (Van Wyk 1996; Van Wyk \& Smith

\footnotetext{
*To whom correspondence should be addressed
}

E-mail: kiboko@florafaunaman.com
2001). A study by Kirkwood \& Midgley (1999) investigated the variations of Sand Forest throughout northern Maputaland and established the presence of at least two variants, with Eastern Sand Forest represented in Tembe Elephant Park, Sileza Nature Reserve, Phinda Game Reserve, and False Bay and Western Sand Forest occurring in Ndumo Game Reserve and Mkuzi Game Reserve. Each of these variants has been further subdivided into several subtypes representative of local variations.

Sand Forest shows a high level of both plant and animal endemism, and is considered as the rarest and most valuable vegetation type in northern Maputaland (Van Wyk \& Smith 2001; Botes et al. 2006; Matthews 2006). While the importance of Sand Forest has been clearly established, its structure has not been fully analysed (Matthews et al. 1999; Matthews et al.2001; Izidine et al.2003; Brookes 2004; Gaugris et al. 2004) and many descriptions of its dynamics are based on conjecture (Matthews 2006) and are often contradictory (Van Rensburg et al.2000a). The phytogeographic affinities and similarities of Sand Forest with Afromontane and Coastal forests (Van Rensburg 
et al. 1999; Matthews et al. 2001) suggest that Sand Forest may be a relict of previous climatic conditions (Matthews 2006). Many authors agree that under the current climatic conditions, Sand Forest may be transformed into woodlands (Van Rensburg et al. 1999; Van Rensburg et al. 2000b; Botes et al. 2006; Matthews 2006).

Although Sand Forest is rare in South Africa, it is more widespread in Mozambique (Izidine et al. 2003; Matthews 2006). Nevertheless, the degree of endemism and abundance of rare species (Matthews et al. 2001) justifies conserving Sand Forest in South Africa. Sand Forest has high levels of $\alpha$ - and $\beta$-diversity (Matthews 2006), implicating that large tracts of land, holding many patches of the vegetation type will be required to conserve a representative sample of such a diverse vegetation type (Matthews 2006). Tembe Elephant Park in South Africa conserves the largest portion of the Sand Forest in the country (Matthews et al. 2001). However, elephants (Loxodonta africana) impact on Sand Forest, and doubt exists as to whether the Sand Forest can sustain such a level of constant animal disturbance (Matthews et al. 2001; Botes et al. 2006; Guldemond \& Van Aarde 2007; Gaugris 2008). Moreover, the survival of Sand Forest outside formally conserved areas is at risk due to the human population growth $(15.22 \%$ between 1993 and 2001, Peteers 2005). Therefore, to conserve Sand Forest for the foreseeable future, it is critical to understand Sand Forest dynamics and the forces driving the dynamics, whether within a progressive or retrogressive successional pattern.

The present study uses data collected to investigate the utilization of woody plants by herbivores and humans in northern Maputaland to classify the woody plant communities of Sand Forest in the Tembe Elephant Park. The aims of the study are to provide a detailed analysis of Sand Forest floristics and structure and to describe these attributes in terms of the forces shaping them.

\section{STUDY AREA}

Tembe Elephant Park (Tembe) was created in 1983 with the dual mandate of conserving the region's rare Sand Forests and the remnants of the Maputaland coastal African elephant population (Matthews 2006; Morley 2005; Guldemond \& Van Aarde 2007). The park covers approximately 30000 ha and is covered by a mix of woodlands of varying densities in the midst of which patches of Sand Forest occur.

The land covered by the Tshanini Community
Conservation Area (Tshanini) in the Manqakulane rural community (6 km south of Tembe) was set aside for conservation purposes in 1993, and tribal rules ensured that its utilization was kept to an absolute minimum (Gaugris et al. 2004). Tshanini covers 2420 ha, of which nearly half is Sand Forest. This conservation area was devoid of animals until the recent (2004) fencing and subsequent release of seed populations of nyala (Tragelaphus angasii) and impala (Aepyceros melampus). Tshanini's vegetation was investigated in 2001 and it was hypothesized that its Sand Forest represented a stage in the successional pathway that has a low level of disturbance but is under climatic control (Gaugris et al. 2004).

The current view is that Sand Forest in Maputaland is comprised of two floristically linked, but structurally different, (sub) communities (Matthews et al. 2001; Izidine et al. 2003; Gaugris et al. 2004), namely the Short Sand Forest and the Tall Sand Forest, for which the names of Licuáti Thicket and Licuáti Forest were recently proposed (Izidine et al. 2003; Mucina \& Rutherford 2006). The Short Sand Forest is described as a short (5-6 m high), dense, single layer, thicket-like vegetation, while Tall Sand Forest reaches canopy heights of $12 \mathrm{~m}$, with emergents at $15 \mathrm{~m}$, and a typical multi-layered forest structure (Matthews et al. 2001; Izidine et al. 2003; Gaugris et al. 2004; Matthews 2006; Mucina \& Rutherford 2006).

Sand Forest grows in a relatively low rainfall area, atypical of forest, on homogeneous, deep, nutrient poor, acidic ( $\mathrm{pH} \mathrm{5-6)}$ sandy substratum (Matthews et al. 2001; Matthews 2006). Rainfall, mist, and soil moisture content have been proposed as important mechanisms regulating the persistence of Sand Forest (Matthews 2006). There have been relatively few quantitative studies on the vegetation type and many of the hypotheses pertaining to its dynamics rest on little actual and verified knowledge (Matthews 2006).

\section{METHODS}

\section{Field sampling}

The research was conducted in Tembe during the dry winter period of 2004 (May to October). Stratification of the area was based on an analysis of the vegetation map of Matthews et al. (2001) and transects were randomly placed within the stratified units. Owing to management restrictions, transect placement was limited to areas alongside the road network of the park. Therefore, transects were placed at least $50 \mathrm{~m}$ away from little-used 
management tracks and at least $100 \mathrm{~m}$ away from more established tourist tracks to avoid roadinduced bias as much as possible.

The exact geographical coordinates (map datum: WGS 84, Lat-Long coordinates) of all transects were recorded using a Global Positioning System device. The methodology used in the present study was designed primarily to evaluate vegetation structure and herbivory levels and a full description of the method is provided in Gaugris (2008). The present paper only reports on the floristics and some elements of vegetation structure. Transect length and width varied based on the general vegetation density $(25 \times 2 \mathrm{~m}$ for a dense homogeneous thicket to $50 \times 10 \mathrm{~m}$ for a Tall Sand Forest site). All woody plants (defined here as plants with an erect to scrambling growth form and with a ligneous trunk) $\geq 0.4 \mathrm{~m}$ height and $\geq 1.0 \mathrm{~cm}$ stem diameter encountered in the transects were identified to the species and measured, while those of dimensions below these cut-offs were only measured along one half of the transect area. A total of 59 transects were sampled in the Sand Forest of Tembe.

For each woody plant the following measurements were recorded: tree height; the height to the base of the canopy (defined as the height where the larger lowest branches were found); the largest canopy diameter (D1) and the diameter of the canopy perpendicular to it (D2); and stem circumference. Stem diameters of larger trees were measured at $100 \mathrm{~cm}$ above ground whenever possible, while for smaller plants the measurements were taken above the basal swelling.

\section{Data analysis}

The main objective of the study was to investigate current levels of vegetation utilization by mammalian herbivores and the emphasis was on obtaining data of common rather than rare plant species. Therefore, the methodology does not lend itself to a rulebook phytosociological study. The phytosociological classification presented here is based solely on trees and woody plants such as lianas and small shrubs and not the whole range of plant forms normally associated with a phytosociological study. Additionally, the data presented here is restricted to Tembe Sand Forest, and therefore do not show the relationships between the Sand Forest and woodlands.

\section{Classification}

The canopy cover of each species per plot was calculated as a percentage of the plot area. These
Table 1. Braun-Blanquet cover-abundance values (Mueller-Dombois \& Ellenberg 1974) and their percentage cover equivalents used in the present study to classify the Sand Forest in the Tembe Elephant Park area, Maputaland, northern KwaZulu-Natal, South Africa.

\begin{tabular}{ccc}
$\begin{array}{l}\text { Braun-Blanquet } \\
\text { cover-abundance } \\
\text { value }\end{array}$ & $\begin{array}{c}\text { Equivalent percentage } \\
\text { cover }(\%)\end{array}$ & $\begin{array}{c}\text { Ordination } \\
\text { values }\end{array}$ \\
\hline$r$ & $<0.9$ & 1 \\
+ & $\geq 0.9$ but $<2.0$ & 2 \\
1 & $\geq 2.0$ but $<4.0$ & 3 \\
$2 m$ & $\geq 4.0$ but $<8.5$ & 4 \\
$2 a$ & $\geq 8.5$ but $<19.0$ & 5 \\
$2 b$ & $\geq 19.0$ but $<37.5$ & 6 \\
3 & $\geq 37.5$ but $<62.5$ & 7 \\
4 & $\geq 62.5$ but $<87.5$ & 8 \\
5 & $\geq 87.5$ & 9 \\
\hline
\end{tabular}

canopy cover percentage values were converted into Braun-Banquet cover-abundance values (Mueller-Dombois \& Ellenberg 1974) (Table 1). These calculated values represent overestimates of cover because it was not possible to compensate for overlap between canopies of different individuals. Data were analysed following Braun-Blanquet procedures (Mueller-Dombois \& Ellenberg 1974) using the TURBOVEG and MEGATAB computer packages (TURBOVEG for Windows version 1.97, Hennekens \& Schaminee 2001).

In order to describe diagnostic groups, because we worked with a dataset restricted to tree species, and in accordance with the reference methodology described in Mueller-Dombois \& Ellenberg (1974), we arbitrarily set the minimum frequency of occurrence of a species within its group of occurrence at $20 \%$. This lower threshold remains higher than the minimum of $10 \%$ frequency of occurrence recommended by these authors, but is lower than the standard of $30 \%$ frequency of occurrence normally applied in phytosociological classifications (Mueller-Dombois \& Ellenberg 1974). However, for the purposes of naming communities associated with these diagnostic groups, we only used species with a frequency of occurrence $>30 \%$.

To describe the structure of each vegetation unit in the classification, the density of woody individuals in each of the following height classes was calculated:

- undergrowth: individuals $=0-<5 \mathrm{~m}$ tall

- first layer: individuals $=5-<8 \mathrm{~m}$ tall

- second layer: individuals $=8-<10 \mathrm{~m}$ tall

- canopy: individuals $=10-<12 \mathrm{~m}$ tall 
- emergents: individuals $=12-<14 \mathrm{~m}$ tall

- tall emergents: individuals $=14-<16 \mathrm{~m}$ tall

- very large trees: individuals $=16 \mathrm{~m}$ tall.

\section{Ordinations}

To complement the classification, the Tembe Elephant Park 2004 data were analysed using a correspondence analysis (CA) indirect gradient ordination (Kent \& Coker 1996). The CA was performed using CANOCO for Windows version 4.52 (Ter Braak 2003). Parameters were set for an analysis without data transformation (see Table 1), focusing on inter-sample distance. No species weights or sample weights were specified, and no down-weightings of rare species were applied. Two CA ordinations were conducted. First, using the complete dataset for Tembe Elephant Park collected in 2004, then using the dataset restricted to a selection of Sand Forest plots.

Another ordination was performed incorporating the Sand Forest relevés of Tembe Elephant Park surveyed in 1996 (Matthews et al. 2001) and Tshanini Community Conservation Area surveyed in 2001 (Gaugris et al. 2004) after all non-woody species were omitted. Because the present study overestimated cover-abundance, the cover-abundance values of the two additional datasets were artificially strengthened by one level (i.e. a cover abundance value of $2 a$ became a $2 b$ ). A CA ordination with the same parameters as above was performed.

\section{RESULTS}

A total of 59 plots and 104 species were analysed from the 2004 sample of Sand Forest vegetation in Tembe and 7201 individual trees were sampled in the Sand Forest association, 1430 (19.86\% of the sample) of which were multi-stemmed, while 171 ( $2.37 \%$ of the sample) of the sampled trees were dead.

\section{Classification}

The classification of the 2004 woody Sand Forest species data strongly suggested the presence of at least three vegetation units that could be seen as communities in the Sand Forest association of Tembe Elephant Park. These units were diffuse and represented a gradual transition from the left to the right of the phytosociological table with a large number of species shared between units. Some units were defined more by the absence of species groups than the presence of diagnostic species. The first unit (community 1 ) was represented by 16 transects, the second unit (community 2) by 32 transects, while the third unit (community 3) was represented by 11 transects.

Community 1 was defined by Strychnos decussata and Afzelia quanzensis in species group $\mathrm{C}$, and two variations of the community were found. In the first variation Manilkara concolor (species group A) was diagnostic, while in the second variation Dalbergia obovata and Cavacoa aurea (species group B) were diagnostic (Table 2). Species groups E, F and I were not represented within community 1 , but links with community 2 were obvious within species groups $\mathrm{D}$ (Balanites maughamii) and $\mathrm{G}$ (Newtonia hildebrandtii and Vepris lanceolata). Links with communities 2 and 3 existed within species group $\mathrm{H}$ (Uvaria lucida and Boscia filipes). Community 1 had the highest number of woody species sampled in a transect (35 species) and the highest mean number of woody species per transect $($ mean $=26$, S.E. $=$ 1.26). Compared to the other communities it also had the highest density of trees in the canopy (Table 3), but the lowest density of woody plants in the undergrowth. The number of emergents and tall emergents in community 1 were much higher than in the other two communities, and the canopy typically reached a height of 12 to $14 \mathrm{~m}$.

Community 2 was defined by a common pool of species shared with community 1 such as Newtonia hildebrandtii and Wrightia natalensis (species group $G$ ), but also a common group of species shared with community 3 such as Brachylaena huillensis and Cassipourea mossambicensis (species group I). Community 2 showed a transitional character with species groups $\mathrm{D}$ (Balanites maughamii), $\mathrm{E}$ (Combretum celastroides) and $\mathrm{F}$ (Combretum mkuzense) contributing to the different variants. Community 2 had the second highest mean number of woody species sampled per transect (mean $=23.59$, S.E. $=0.76$ ) and the highest number of species in one transect was 30 species. The total density of woody species per hectare was lowest in this community (Table 3 ), where the canopy reached between 10 and $12 \mathrm{~m}$.

Community 3 was the least defined group, and was characterized by an absence of species groups $A$ to $G$ rather than the presence of any diagnostic species group. A link with community 2 was clearly present in species group I (e.g. Brachylaena huillensis), while species group $\mathrm{H}$ (Uvaria lucida) linked all three communities. A total of 29 species from groups $A$ to $G$ were absent within community 3 . This community had the 


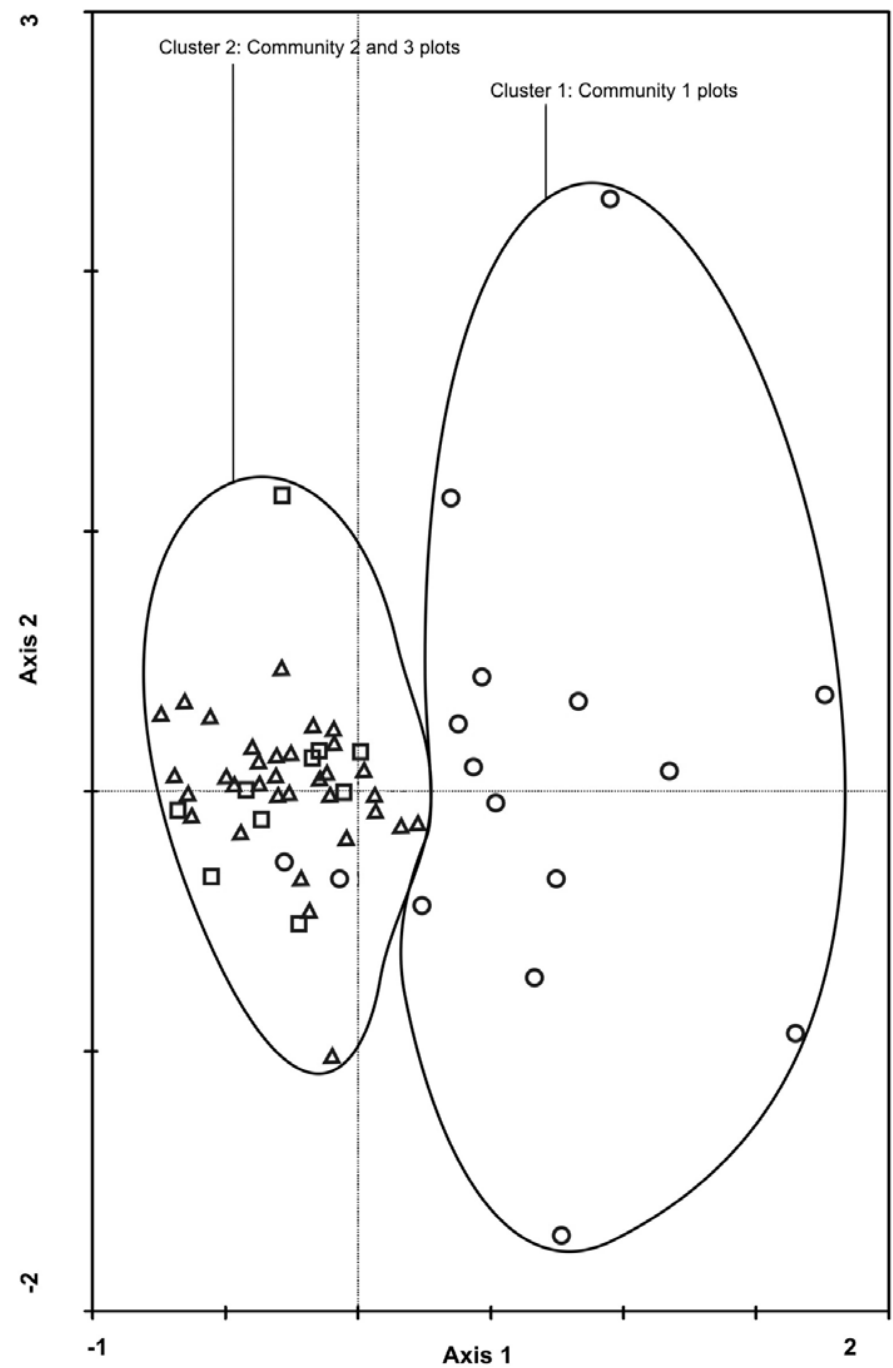

Fig. 1. Scatter plot of the correspondence analysis on the 2004 Sand Forest woody species assemblages in Tembe Elephant Park, Maputaland, South Africa. Eigenvalues for axis $1=0.29$, and for axis $2=0.26$. The circles represent transects of community 1 , the triangles represent transects of community 2 , and the squares represent transects of community 3 .

lowest mean number of sampled woody species per transect $($ mean $=20.72$, S.E. $=0.95)$ and the highest number of woody species in one transect was 27 woody species. The woody plants in community 3 remained short, and the upper levels of the canopy were located between 8 and $10 \mathrm{~m}$. Scattered taller trees (Cleistanthus schlechteri, Dialium schlechteri, Erythrophleum lasianthum) with broad canopies and reaching heights of 10 to $12 \mathrm{~m}$ were noted. The community had a dense undergrowth and first layer.

Species group $\mathrm{J}$ represented the common species, with Drypetes arguta, Pteleopsis myrtifolia,
Dialium schlechteri, Croton pseudopulchellus, Toddaliopsis bremekampii, Cola greenwayi, Hymenocardia ulmoides, Cleistanthus schlechteri, Ptaeroxylon obliquum and Strychnos henningsii ubiquitous, with generally high cover-abundance values.

\section{Ordinations}

The first CA ordination based on the full 2004 Tembe Elephant Park Sand Forest dataset produced two main clusters along the first axis (Fig. 1). The cluster on the right of axis 1 , in the positive values, contained 14 transects $(87.5 \%)$ of 


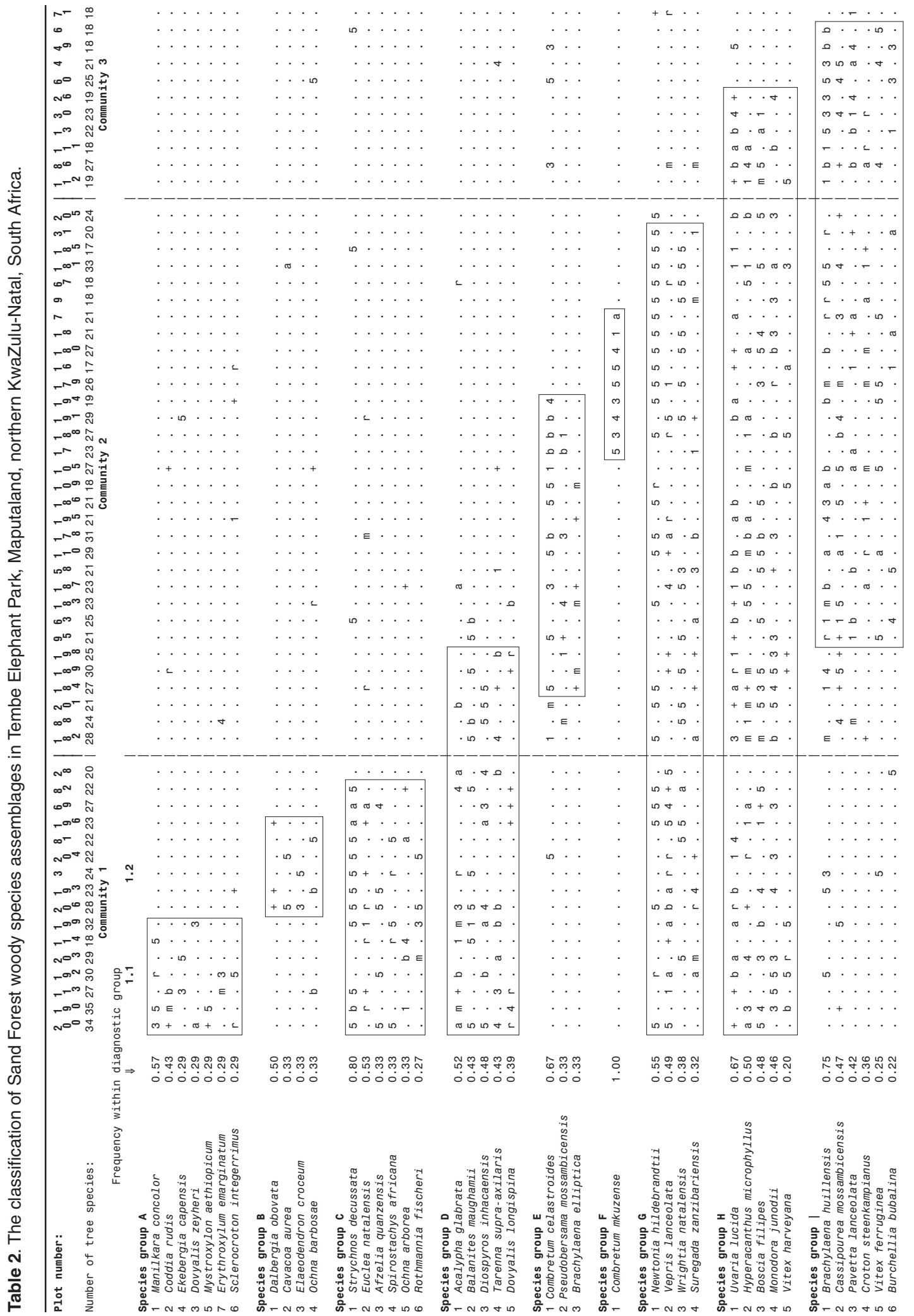




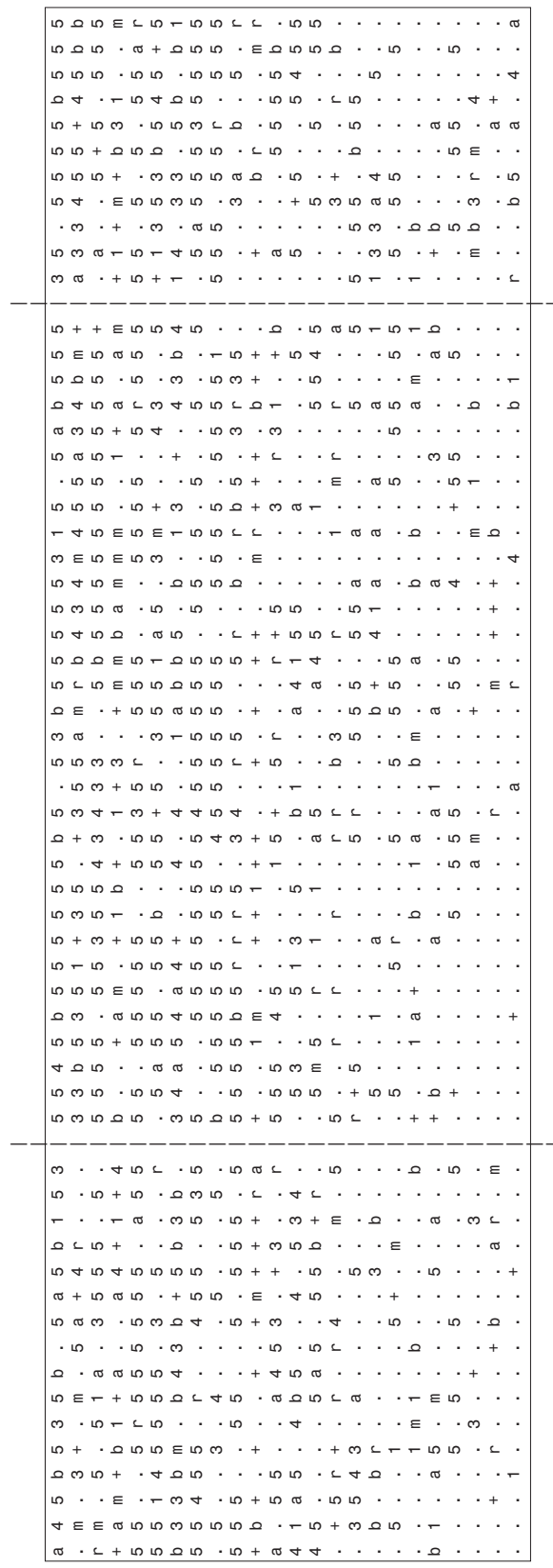

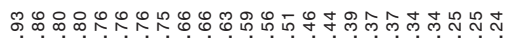

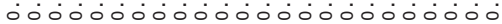

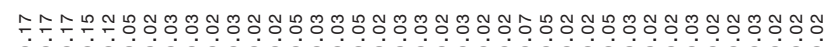
0000000000000000000000000000000
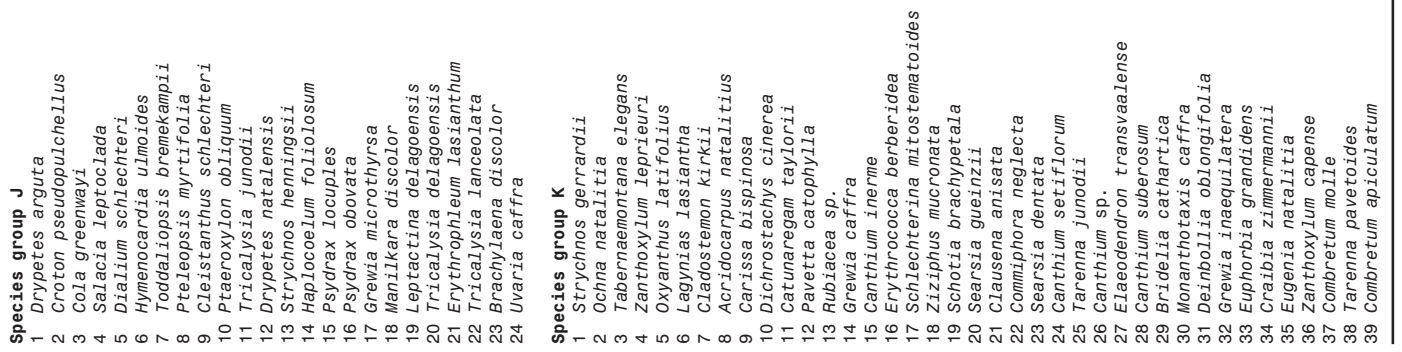
community 1 . On the left, predominantly in the negative values, the transects from communities 2 and 3 appeared indistinguishable. Because community 1 appeared distinct, and most of the variation was explained along axis 1 , the transects that defined cluster 1 were removed and a second ordination run to uncover any possible underlying pattern (restricted dataset).

In the second CA ordination, based on the restricted dataset, most of the separation occurred along axis 2 (Fig. 2). Cluster one (top) contained eight transects of community 3 in the classification. Cluster two (bottom) represented the transects from community 2. However, the two clusters grade into one another and there is no distinct discontinuity.

The third CA ordination, using the additional data from the studies of 1996 in Tembe Elephant Park by Matthews et al. (2001) and 2001 in Tshanini Community Conservation Area by Gaugris et al. (2004) incorporated a temporal component (Fig. 3). The dataset from the present study, collected in 2004, appeared to the left of axis 1, mostly within the negative values along axis 1 , and stretched along axis 2 . The dataset from Matthews et al. (2001), representing data sampled in 1996, was centrally located between the 0 and 1 values along axis 1 . Within this cluster, the Tall (see Fig. 3) and Short Sand Forest subcommunities as defined by Matthews et al. (2001) were fairly well separated. The dataset from Tshanini Community Conservation Area sampled in 2001 appeared on the right of axis 1 in two distinct subclusters (see Fig. 3). The subcluster furthest to the right represented the Short Sand Forest community described by Gaugris et al. (2004), and the other the Tall Sand Forest community.

It was noteworthy that all three studies had clearly separated clusters, organized along axis 1 . A further separation appeared within the studies conducted in Tembe (1996 and 2004) along axis 2 separating Short and Tall Sand Forest (1996), and community 1, 2 and 3 observed in our study (2004). Moreover, it was equally noticeable that in the scatter plot for the Tall and Short Sand Forest of the Tshanini Community Conservation Area the clusters (2001 surveys) were separated more along axis 1 than axis 2 . Finally, the clusters for the Short and Tall Sand Forest groups in Matthews et al. (2001) were well separated along the vertical axis (Axis 2), and were to an extent concordant with the vertical position of clusters representing communities 2 and 3 of the present study, while the 


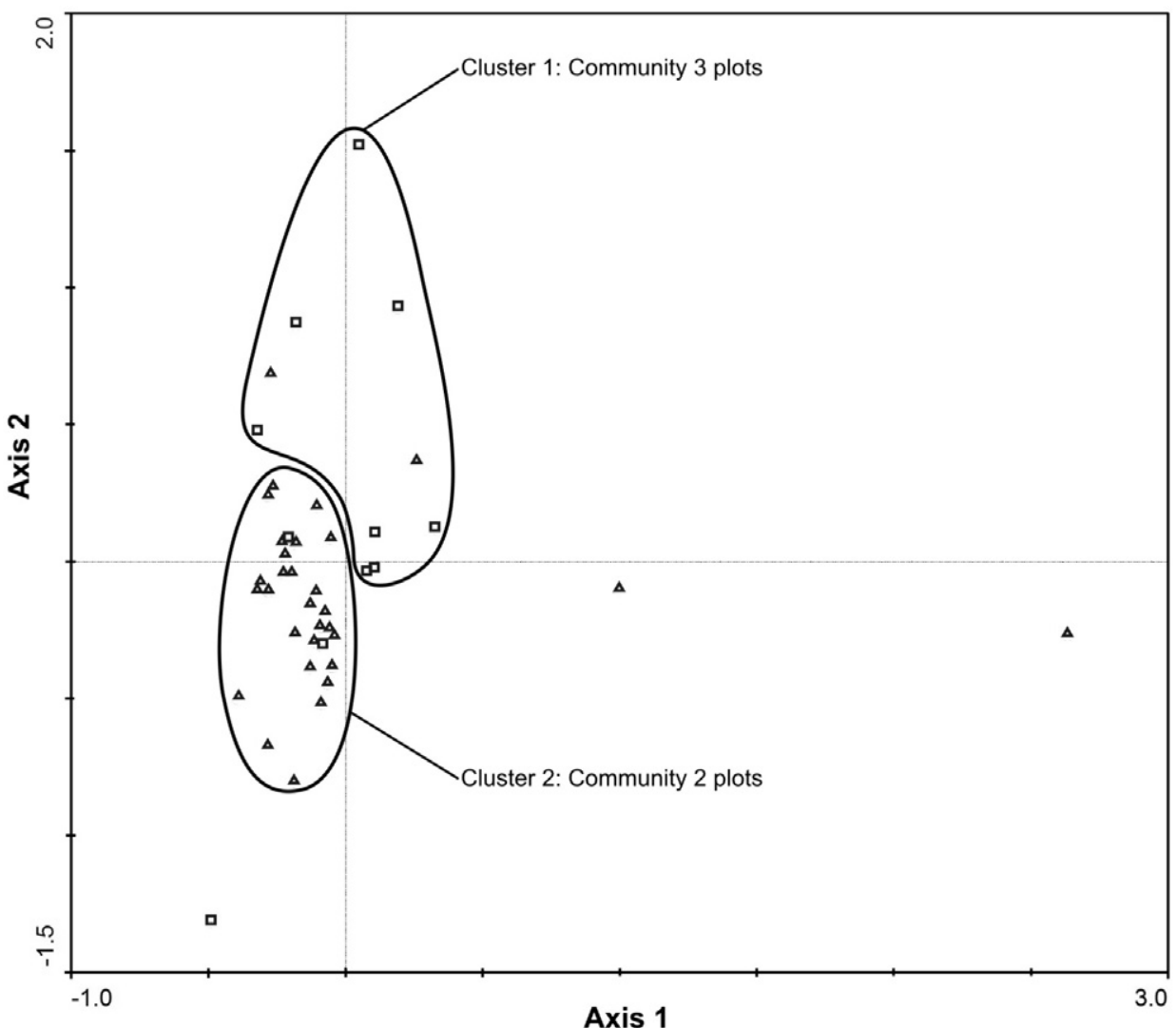

Fig. 2. Scatter plot of the correspondence analysis on the 2004 restricted Sand Forest woody species assemblages in Tembe Elephant Park, where the transects from community 1 were removed. Eigenvalues for axis $1=0.28$, and for axis $2=0.23$. The triangles represent transects of community 2 , and the squares represent transects of community 3 .

cluster of community 1 was higher along Axis 2 (Fig. 3).

\section{DISCUSSION}

The presence of a gradient of woody species assemblages that can be subdivided into at least three communities, with variations within two of the communities, is a new finding for Sand Forest. Previous studies had identified the presence of only two communities: the Tall and Short Sand Forest communities (Matthews et al. 1999; Matthews et al. 2001; Izidine et al. 2003; Gaugris et al. 2004).

Additionally, the delineation of Short Sand Forest as described in the previous studies is not as clear-cut as previously thought. Community 3 has the lowest canopy height of the three subcommunities with a canopy layer established between 8 and $10 \mathrm{~m}$. This height is approximately $3 \mathrm{~m}$ higher than described previously, and it could be argued that such a height no longer fits the term of Thicket as described by previous studies (Matthews et al. 2001; Izidine et al. 2003). Perhaps the most noteworthy feature of the classification is the clear gradient between the three communities, with obvious links between each of them. This classification lends some credence to the hypothesis advanced by Gaugris et al. (2004) that Short Sand Forest changes into Tall Sand Forest in time, and that the different forms are stages in a successional chronosequence.

The present study therefore proposes the following revised terminology:

- The Brachylaena huillensis-Drypetes arguta Short Sand Forest community (for community 3)

- The Newtonia hildebrandtii-Cola greenwayi Tall Sand Forest community (for community 2)

- The Strychnos decussata-Afzelia quanzensis Mature Sand Forest community (for community 1).

For their inherent descriptive values, and their utilization in the most recent work on the vegetation 


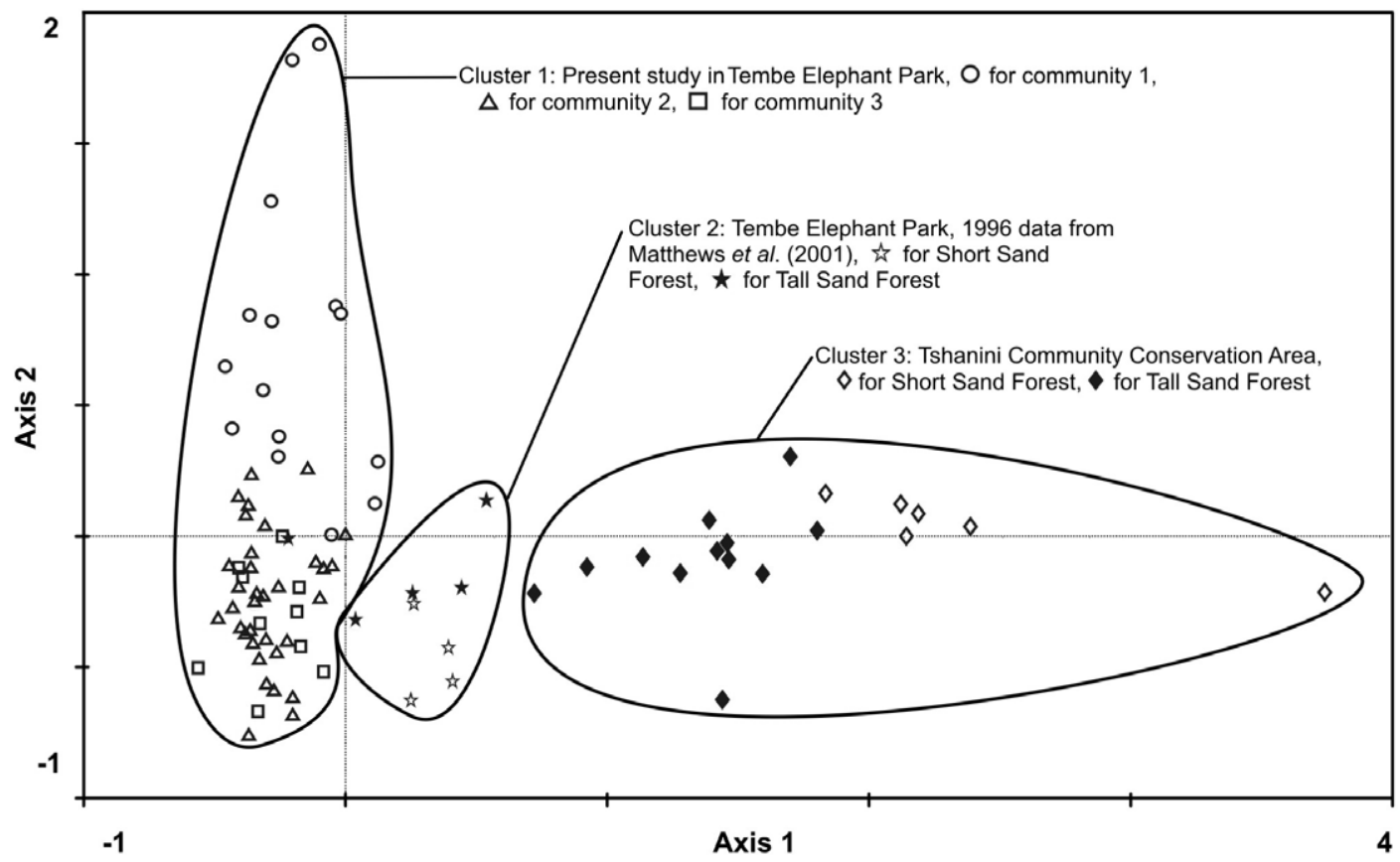

Fig. 3. Scatter plot of the correspondence analysis on Sand Forest woody species for the present study dataset (see Figs 1 \& 2 for detail), the dataset from Matthews et al. (2001) (solid and open stars) and the dataset from Gaugris et al. (2004) (solid and open lozenges) in Maputaland, South Africa. Eigenvalues for axis $1=0.46$, and for axis $2=0.27$

in South Africa by Mucina \& Rutherford (2006), the Short and Tall Sand Forest names are retained in the proposed nomenclature. The term Short Sand Forest describes the shortest form of this vegetation type, although it is now applicable to areas that may no longer be termed thicket-like. It is here considered to also represent a transitional Short Sand Forest state due to intense animal utilization. The Tall Sand Forest term agrees with its delineation in previous studies (Matthews et al. 2001; Izidine et al. 2003; Gaugris et al. 2004; Mucina \& Rutherford 2006). However, in the present study it is intermediate in height, appeared most widespread and could be a possible transition between Short and Mature states. The community described as Mature Sand Forest represented a newly described unit of the Sand Forest vegetation. It is possibly the most mature successional stage of this forest type at present.

The naming of communities proposed above follows recommendations set by Mueller-Dombois \& Ellenberg (1974) for this type of analysis but is based on the fact that only woody assemblages were sampled and could therefore be used as community determinants. This naming and description of communities is therefore preliminary until a full phytosociological analysis has been conducted.

The ordinations offer further evidence of the strong ties between these three communities. The first ordination brought forward that community 1 is clearly distinct from the other two, while the second ordination partially separated communities 2 and 3 . It appears that communities 2 and 3 have many similarities in terms of cover-abundance, which confirms the ill-defined distinctions seen at the classification level.

The results from the third ordination are most interesting and three aspects are noteworthy. The first aspect represents a timeline in Tembe, as showed by the position of the clusters from the current study in Tembe (2004) and those of the previous study (1996). Because both studies sampled the Sand Forest in Tembe, and fire is not considered an agent of change in Tembe's Sand Forest (Matthews 2006), the differences observed most likely reflect changes associated with eight years of increasing animal utilization linked to increasing animal numbers. Population counts for Tembe show that most mammal populations have increased over the period considered, most noticeably, the population of greater kudu (Tragelaphus strepsiceros) increased from 290 to $>530$ 
individuals between 2000 and 2005, while the nyala population increased from 300 to $>1800$ individuals over the same period (Matthews 2000, 2005). Moreover, the elephant population grew from 100 individuals in 1996 to over 200 animals in 2004 (Morley 2005). The changes associated with an increase in elephant and other herbivore numbers in a small reserve, in an environment subject to severe rainfall fluctuations have been described in other parts of Africa and have led to drastic changes in vegetation cover (Lombard 2001; Western 2004). It is highly likely that a similar situation would develop in Tembe, as it is a small reserve, is completely fenced off, and it is subject to large annual rainfall variations (Gaugris et al. 2007).

The second aspect, and possibly a confirmation of the above hypothesis, is the position of the Tshanini cluster, representing data collected in 2001. Again fire is not considered an agent of disturbance in the Sand Forest of that area (Gaugris 2004). Furthermore, this community reserve had been under no animal utilization pressure (only a few small herbivores remain in low numbers, see Van Eeden 2005) since the early 1980s, while human utilization had been excluded through tribal rule since 1993 (Gaugris 2004; Gaugris et al. 2004). The cluster from Tshanini therefore represents Sand Forest under no utilization or as little disturbance as may be possible under current conditions. Axis 1 is therefore interpreted as representing a gradient in time and intensity of utilization. Of further interest with regards to the lay out of the Tshanini Tall and Short Sand Forest subclusters, is the fact that the two vegetation types were differentiated along axis 1 rather than axis 2, as observed for the Tembe studies. This difference hints at a temporal differentiation rather than because of utilization, as is most likely the case in Tembe. This lends further support to the hypothesis of Short and Tall Sand Forest being similar forest types at different successional stages.

The third aspect is the position of the Short and Tall Sand Forest groups within the Tembe 1996 (Matthews et al. 2001) and Tembe 2004 (Gaugris et al. 2004) clusters. These groups were fairly well separated in the Tembe 1996 cluster but no longer in the 2004 cluster. It is possible that under mounting animal utilization pressure, the Short and Tall Sand Forest described by Matthews et al. (2001) changed to such an extent that the two communities have become much less discernible. These changes can possibly be attributed to the opening of numerous canopy gaps by elephants (termed elephant refuges, see Shannon 2001) in the Sand Forest, but especially in the Short Sand Forest (Shannon 2001). The Short Sand Forest habitat appears ideally suited to elephant feeding habits (Guldemond 2006; Morley 2005) due to an abundance of feeding material at an appropriate height. The creation of such canopy gaps by elephants combined with aided secondary dispersal through zoochory has most likely increased the opportunities for canopy plant species of Tall Sand Forest vegetation to emerge or establish. In contrast to this blurring of characteristics between the Tall and Short Sand Forest units in Tembe because of large herbivore related disturbance, these units appear markedly distinct in Tshanini, following a continued absence of disturbance over a similar time frame.

There appears to be two major gradients describing Sand Forest dynamics, namely time and disturbance level, with time related changes directly affected by disturbance levels. Tshanini reveals an image of Sand Forest in a least disturbed stage for current times in this sector of Maputaland. It is argued that the state of Sand Forest in Tshanini is probably closest to the way the ecology of Maputaland functioned before the advent of modern conservation practices, with large herbivores roaming through Maputaland unhindered and following cyclical migration routes (Guldemond 2006). Disturbance of Sand Forest patches was most likely a cyclical and irregular event, and time between disturbance events was the main driver for vegetation changes. However, since the protection of Tembe in 1983, disturbance has become a regular if not constant element of the ecology of the fenced-off area and the cyclical nature of disturbance has disappeared. It is likely that disturbance by large herbivores is driving Sand Forest changes on a much more rapid scale than previous natural conditions would have done.

The situation in Mozambique (Izidine et al. 2003) shows a striking similarity to what has been observed in Tshanini, namely clearly defined Short and Tall Sand Forest units. While Mozambique's forests are under mounting pressure from human utilization now, it can be assumed that their ecology has been similar to that described above until fairly recently because of the civil war conditions in Mozambique until 1992. Wildlife incursions were few and far between, and therefore Sand Forest only reacted to sporadic disturbance events. 
Community 1 is as an altogether new form of Sand Forest, previously undescribed. It may be explained simply through the low sample sizes of previous studies, which could have led to this form of Sand Forest being missed in the sampling effort. However, it can also be explained by changed understorey conditions in Tall Sand Forest patches by elephants (Shannon 2001). In a similar way as for Short Sand Forest, the changed conditions (especially trampling and light, see Gaugris 2008) induced by large herbivores could have led to the establishment of new plant species, while the breaking down of some canopy trees may have released other species from limiting conditions, thereby allowing them to grow taller unhindered.

The situation in 2004 therefore most likely reflects Sand Forest as being a mosaic of the same forest type at different stages of successional progression as proposed by Gaugris et al. (2004) and Gaugris \& Van Rooyen (2007). However, in Tembe's case, this appears as accelerated retrogression over a relatively short time. A similar mosaic nature has been described for tropical rain forests in other studies (Whitmore \& Burslem 1996; Burslem \& Whitmore 1999).

The following successional pathway is proposed: because the soil and rainfall conditions are so limiting, it appears logical that the stunted forest form known as Licuati Thicket or Short Sand Forest would develop first in the sequence, and its physiognomic description follows the descriptions for Tembe from the 1996 sample (Matthews et al. 2001), Tshanini from the 2001 sample (Gaugris et al. 2004), and observations from southern Mozambique (Izidine et al. 2003). In view of the present results and observations on Short Sand Forest in Tshanini and Mozambique, it is further hypothesized that Licuati Thicket and Short Sand Forest are two different structural types, with Licuati Thicket representing an undisturbed structural vegetation unit preceding the already disturbed Short Sand Forest structural vegetation unit. Through a combination of time, infrequent animal incursions, especially by megaherbivores that create favourable conditions for the canopy tree species of Tall Sand Forest to emerge and for the successional pathway to continue, Short Sand Forest progresses into community 2 and eventually community 1 described in the present classification. Community 2 is related to the Tall Sand Forest or Licuati Forest described by previous studies (Matthews et al. 2001; Izidine et al. 2003; Gaugris et al. 2004; Mucina \& Rutherford 2006).
The above-proposed pathway is well supported by the classification in the present study as well as the third ordination.

The above hypothesis implies small changes occurring over a long time, leading to a mosaic pattern of Sand Forest in Maputaland, akin to a successional chronosequence. Because these changes appear to have occurred at a slow rate over the past few millennia (see a condensed geological history of Maputaland in Matthews 2006), Sand Forest may appear to be locked 'in stasis' as described by several authors (Van Rensburg et al. 1999; Van Rensburg et al. 2000a; Matthews 2006). However, because of the rapid changes described for Tembe in the present study, we are in favour of describing the Sand Forest rather as a dynamic vegetation type that is well adapted to its environment, and showing a slow progressive succession that is tied to small natural disturbance events to progress along the successional pathway. Furthermore, the vegetation is highly responsive to cyclic small to medium disturbance events engendered by small to megaherbivore incursions, which induce rapid changes. We therefore argue that biotic disturbances in Sand Forest lead to increased structural complexity of the vegetation type and possibly induce a mature climax community state. However, as yet we have insufficient information to say whether Sand Forest integrity can be maintained at the current animal disturbance level.

In conclusion, the structure and floristics of Sand Forest are a consequence of its dynamics, and the dynamics of Sand Forest appear largely driven by the disturbance regime or lack thereof (mounting animal pressure or lack of disturbance altogether) that prevail in the area considered.

\section{ACKNOWLEDGEMENTS}

We thank two anonymous referees for their valuable comments and insights. We are grateful to Sabelo Mthembu and Caroline Vasicek who assisted with the fieldwork; the management staff of Tembe Elephant Park and Ezemvelo KwaZuluNatal Wildlife for the use of research facilities and logistical support; the Centre for Wildlife Management of the University of Pretoria and the University of Pretoria for the material and financial support of the project. We are also grateful to Bruce Page and Rob Slotow of the School of Life and Environmental Sciences of the University of Natal, Durban, KwaZulu-Natal, South Africa, for assistance in supporting the official adminis- 
tration of the project and processing the raw data. Noel Van Rooyen is thanked for his help in finalizing the classification table. This research project was supported by the National Research Foundation of South Africa under Grant Number 2053522.

\section{REFERENCES}

BOTES, A., McGEOCH, M.A. \& VAN RENSBURG, B.J. 2006. Elephant- and human-induced changes to dung beetle (Coleoptera: Scarabaeidae) assemblages in the Maputaland Centre of Endemism. Biol. Conserv. 130: 573-582.

BROOKES, P.A. 2004. Modelling tree resource harvesting on communal land in the Maputaland Centre of Endemism. M.Sc. dissertation, University of Kent at Canterbury, Canterbury.

BURSLEM, D.F.R.P. \& WHITMORE, T.C. 1999. Species diversity, susceptibility to disturbance and tree population dynamics in tropical rain forest. J. Veg. Sci. 10: 767-776.

EVERARD, D.A., VAN WYK, G.F. \& MIDGLEY, J.J. 1994. Disturbance and the diversity of forests in Natal, South Africa: lessons for their utilization. Strelitzia 1: 275-285.

EVERARD, D.A., MIDGLEY, J.J. \& VAN WYK, G.F. 1995. Dynamics of some forests in KwaZulu-Natal, South Africa, based on ordinations and size class distributions. S. Afr. J. Bot. 61: 283-292.

GAUGRIS, J.Y. 2004. Sustainable utilisation of plants in the Manqakulane Conservation area, Maputaland, South Africa. M.Sc. dissertation, University of Pretoria, Pretoria.

GAUGRIS, J.Y. 2008. The impacts of herbivores and humans on the utilisation of woody resources in conserved versus non-conserved land in Maputaland, northern KwaZulu-Natal, South Africa. Ph.D. thesis, University of Pretoria, Pretoria.

GAUGRIS, J.Y., MATTHEWS, W., VAN ROOYEN, M.W. \& BOTHMA, J. du P. 2004. The vegetation of Tshanini Game Reserve and a comparison with equivalent units in the Tembe Elephant Park in Maputaland, South Africa. Koedoe 47: 9-29.

GAUGRIS, J.Y. \& VAN ROOYEN, M.W. 2007. The structure and harvesting potential of the Sand Forest in Tshanini Game Reserve, South Africa. S. Afr. J. Bot. 73: 611-622.

GAUGRIS, J.Y., VAN ROOYEN, M.W. \& VAN DER LINDE, M.J. 2007. Hard wood utilisation in buildings of rural households of the Manqakulane community, Maputaland, South Africa. Ethnobot. Res. \& Applic. 5: 97-114.

GULDEMOND, R.A.R. 2006. The influence of savannah elephants on vegetation: a case study in the Tembe Elephant Park, South Africa. Ph.D. thesis, University of Pretoria, Pretoria.

GULDEMOND, R.A.R. \& VAN AARDE, R.J. 2007 The impact of elephants on plants and their community variables in South Africa's Maputaland. Afr. J. Ecol. 45: 327-335.

IZIDINE, S., SIEBERT, S. \& VAN WYK, A.B. 2003. Maputaland's Licuati forest and thicket, botanical exploration of the coastal plain south of Maputo Bay, with an emphasis on the Licuati Forest Reserve. Veld \& Flora 89: 56-61.

KENT, M. \& COKER, P. 1996. Vegetation description and analysis: a practical approach, 2nd edition. John Wiley \& Sons, Chichester, New York.

KIRKWOOD, D. \& MIDGLEY, J.J. 1999. The floristics of Sand Forest in northern KwaZulu-Natal, South Africa. Bothalia 29: 293-304.

LAWES, M., MACFARLANE, D.M. \& EELEY, H.A.C. 2004. Forest landscape pattern in the KwaZulu-Natal midlands, South Africa: 50 years of change or stasis? Austral Ecol. 29: 613-623.

LOW, A.B. \& REBELO, A.G. 1998. Vegetation of South Africa, Lesotho and Swaziland. Department of Environmental Affairs and Tourism, Pretoria.

MATTHEWS, W. 2000. Large herbivore population estimates for Tembe Elephant Park: August 2000. EKZN Wildlife unpublished report.

MATTHEWS, W. 2005. Large herbivore population estimates for Tembe Elephant Park: November 2005. EKZN Wildlife unpublished report.

MATTHEWS, W. 2006. Contributions to the ecology of Maputaland, southern Africa, with emphasis on Sand Forest, Ph.D. thesis, University of Pretoria, Pretoria.

MATTHEWS, W., VAN WYK, A.B. \& VAN ROOYEN, N. 1999. Vegetation of the Sileza Nature Reserve and neighbouring areas, South Africa, and its importance in conserving the woody grasslands of the Maputaland Centre of Endemism. Bothalia 29: 151-167.

MATTHEWS, W., VAN WYK, A.E., VAN ROOYEN, N. \& BOTHA, G.A. 2001. Vegetation of the Tembe Elephant Park, Maputaland, South Africa. S. Afr. J. Bot. 67: 573-594.

MIDGLEY, J., SEYDACK, A., REYNELL, D. \& McKELLY, D. 1990. Fine-grain pattern in southern Cape plateau forests. J. Veg. Sci. 1: 539-546.

MORLEY, R.C. 2005. The demography of a fragmented population of the savanna elephant (Loxodonta africana Blumenbach) in Maputaland. Ph.D. thesis, University of Pretoria, Pretoria.

MUCINA, L. \& RUTHERFORD, M.C. 2006. The vegetation of South Africa, Lesotho and Swaziland. South African National Biodiversity Institute, Pretoria.

MUELLER-DOMBOIS, D. \& ELLENBERG, H. 1974. Aims and Methods of Vegetation Ecology. John Wiley \& Sons, New York.

PETEERS, O. 2005. Poverty alleviation and sustainable development in Manqakulane, Northern KwaZuluNatal, South Africa: a systemic approach using retrospective remote sensing and GIS. M.A. dissertation, Vrije Universiteit Brussel, Brussels.

SMITH, R.J., GOODMAN, P.S. \& MATTHEWS, W. 2006. Systematic conservation planning: a review of perceived limitations and an illustration of the benefits, using a case study from Maputaland, South Africa. Oryx 40: 400-410.

SHANNON, G. 2001. Using a GIS to investigate the role of elephant paths in vegetation utilisation, Tembe Elephant Park, South Africa. M.Sc. dissertation, University of Kent at Canterbury, Canterbury, U.K.

TER BRAAK, C.J.F. 2003. CANOCO version 4.52: Biometris quantitative methods in the life and earth sciences. Plant Research International, Wageningen University, Wageningen. 
VAN EEDEN, D.G. 2005. Aspects of the ecology and conservation status of selected wildlife in and around Tembe Elephant Park, KwaZulu-Natal, South Africa. M.Sc. dissertation, University of Pretoria, Pretoria.

VAN RENSBURG, B.J., McGEOGH, M.A., CHOWN, S.L. \& VAN JAARSVELD, A.S. 1999. Conservation of heterogeneity among dung beetles in the Maputaland Centre of Endemism, South Africa. Biol. Conserve. 88: 145-153.

VAN RENSBURG, B.J., CHOWN, S.L., VAN JAARSVELD, A.S. \& McGEOGH, M.A.2000a. Spatial variation and biogeography of sand forest avian assemblages in South Africa. J. Biogeog. 27: 13851401.

VAN RENSBURG, B.J., McGEOCH, M.A., MATTHEWS, W., CHOWN, S.L. \& VAN JAARSVELD, A.S. 2000b. Testing generalities in the shape of patch occupancy frequency distributions. Ecology 81: 3163-3177.

VAN WYK, A.E. 1996. Biodiversity of the Maputaland Centre. In: X.M. van den Burgt \& J.M. van Medenbach de Rooy (Eds), The biodiversity of African plants (pp. 198-207). Kluwer Academic Publishers, Dordrecht.

VAN WYK, A.E. \& SMITH, G.F. 2001. Regions of floristic endemism in southern Africa. A review with emphasis on succulents. Umdaus Press, Pretoria.

WESTERN, D. \& MAITUMO, D. 2004. Woodland loss and restoration in a savanna park: a 20 -year experiment. Afr. J. Ecol. 42: 111-121.

WHITMORE, T.C. \& BURSLEM, D.F.R.P. 1996. Major disturbances in tropical rainforests. In: D.M. Newbery, H.H.T.Prins \& N.D. Brown (Eds), Dynamics of tropical communities (pp. 549-565). The 37th symposium of the British Ecological Society. Blackwell science, Cambridge University, U.K.

Corresponding Editor: G.S. Cumming 